\title{
CARBON GAS FLUX FROM THE DEALUL MELCULUI GEOLOGICAL RESEREVE (CORUND, ROMANIA)
}

\author{
B. CZELLECZ1, A. IONESCU ${ }^{2}$, B. M. KIS ${ }^{3}$, L. RAVASZ
}

\begin{abstract}
Carbon gas flux from the Dealul Melcului geological reserve (Corund, Romania). Recent studies have revealed the qualitative and quantitative importance of the free gas emanations from aqueous environments and from soil surfaces in Romania. Interesting mixing zones of different gases can be observed on the boundary between the Miocene sedimentary deposits and Late Miocene volcaniclastics. This study presents the results of investigations of free carbondioxide and methane made in Corund area (Harghita County), at Dealul Melcului geological reserve, where a presumed methane seepage was described in the past. Measurements were performed using a closed chamber method. Our observations and result show the lack of methane emanations, while the maximum value for carbon-dioxide emanation was $458 \mathrm{~g} / \mathrm{m}^{2} /$ day.
\end{abstract}

Keywords: gas flux, methane, carbon-dioxide, Corund

\section{INTRODUCTION}

As gas seeps are important natural sources of greenhouse gas to the atmosphere, Baciu et al. (2017) summarized the so far documented seeps in Romania and estimated that the total $\mathrm{CH}_{4}$ seepage emission in Romania would be on the order of $6000 \mathrm{t} / \mathrm{year}$.

Saline waters, mud volcanoes and the so called everlasting fires (methane gas leakages) denote the presence of hydrocarbon accumulations in the Miocene sediments of the Transylvanian basin. These occurrences exist not just in the middle of the Basin but in the peripheral regions as well.

In Corund area, a tourist guide -like paper, published in 1839, was the first to suggest the possibility of presence of hydrocarbon - methane leakages (Erdödi, 1839). Upwelling of methane was described at the saline water bath, located in the vicinity of Dealul Melcului, now a geological reserve. Recently, as part of wider scientific survey, results of some new, point-wise analyzes regarding the methane release became available from Corund area (Pop, 2014).

Since Corund is located on the volcanic plateau of Gurghiu Mountains, carbon-dioxide rich mineral waters are mostly present in the area. The most recent

\footnotetext{
${ }^{1}$ Babeş-Bolyai University, Faculty of Geography, 400006 Cluj-Napoca, Romania, e-mail: boglarka.czellecz@gmail.com_ravaszlevente95@gmail.com

${ }^{2}$ Babeş-Bolyai University, Faculty of Environmental Science and Engineering, 400294 Cluj-Napoca, Romania, e-mail: artur.ionescu@ubbcluj.ro

${ }^{3}$ Babeş-Bolyai University, Faculty of Biology and Geoology, 400015 Cluj-Napoca, Romania, e-mail: kisboglarka85@gmail.com
} 
and maybe the most detailed analyzes of these waters was made by Kis B. M. in 2013.

As it was shown above, Corund is located at the boundary between the sedimentary deposits of Transylvanian Basin and the volcaniclastic deposits of the Gurghiu Mountains. The chemical characteristics of the mineral water springs are dependent on the geological background of the area. These waters usually contain a mixture of dissolved solids and gases, originated from the two different geological structures.

The first measurements regarding the composition of the emanated gases in Corund area were performed by Vaselli et al. (2002), who demonstrated the dominance of the carbon-dioxide and the presence of methane in the free gas mixture. The same can be concluded about the dissolved gases as well (Italiano et al., 2017).

Gas flux measurements were first made in this area by Pop C. I. in 2014. There were investigated two sites located NV to Corund village. Results of this survey show a carbon-dioxide flux of $1671-1422 \mathrm{~g} / \mathrm{m}^{2} /$ day that corresponds to an average emanation of $2.39 \mathrm{t} / \mathrm{year}$. The methane flux was practically detectable only at one of the studied sites and showed values of $5.86-114.63 \mathrm{~g} / \mathrm{m}^{2} /$ day that gives an emission of $0.0062 \mathrm{t} /$ year.

The aim of this study is to investigate the flux of the free gas emanations in the tight environment of Dealul Melcului geological reserve, located NV to Corund village.

\section{GEOLOGICAL AND GEOCHEMICAL BACKGROUND OF THE STUDY AREA}

The study area is located on the right side of the Corund River, lying near an intermittent tributary of the river. This location (Fig. 1) is marked by the transition between the Pannonian sands, clays, conglomerates and the Late Miocene amphybole- and pyroxene-andesitic volcaniclastics (Ianovici and Rădulescu, 1968; Seghedi et al., 2004).

The sedimentation in the Transylvanian Basin can be considered as a result of the alternation of shallow- and deep-sea environments during the whole Miocene series. The thickness of the sediments in the region exceeds $2000 \mathrm{~m}$ and is made up of the Pannonian sands and clays, the Sarmatian clays, sandstones and the Tortonian clays, marls, sandstones (Ianovici and Rădulescu, 1968). Hydrocarbon gases can be accumulated in both the Tortonian and Sarmatian sands and sandy marls (Ciupagea, 1970). The existence of salt (e.g. Praid, in the vicinity of Corund) can be linked to the Tortonian transgression and it is penetrated into the younger structures along anticlines (Ciupagea, 1970). In Corund area, the presence of high concentration saline mineral water springs indicates that the salt might be at shallow depth under the surface. 


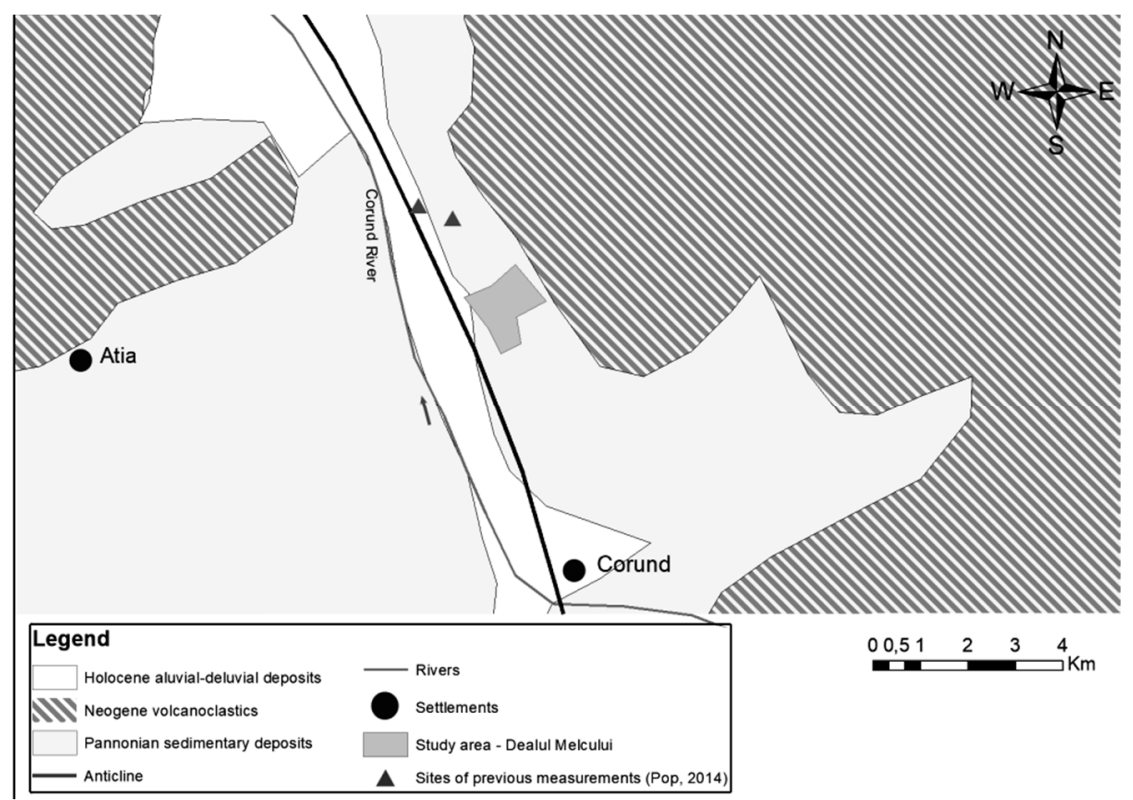

Fig. 1. Geologycal background of the study area (after Ianovici and Rădulescu, 1968)

On the eastern edge of the Transylvanian Basin the marine sediments were affected by the volcanism of the Călimani-Gurghiu-Harghita Mountains (Krézsek and Bally, 2006). In Corund area the Miocene sediments were partly covered by andesitic volcaniclastics originated from the activity of Făncel-Lăpuşna volcanic structure (Seghedi et al., 2004). The upwelling of the post-volcanic gases is favored by deep fractures developed on the western side of the Gurghiu-Harghita Mountains.

The Dealul Melcului geological reserve is made up by thick (up to 5-6 m high) travertine blocks that were deposited from the highly saline, $\mathrm{CO}_{2}$ rich mineral water springs. The mineralogy of these travertines consists of magnesium calcite and aragonite which precipitated depending on the concentration and flow rate of the solutions. The aragonite mineral is seldom present in such temperature and pressure conditions as it is at Corund, that is why the area is considered a geological reserve (Tóth, 2002).

The main spring of the Dealul Melcului is of $\mathrm{Na}-\mathrm{HCO}_{3}-\mathrm{Cl}$ type with temperature of $14^{\circ} \mathrm{C}, \mathrm{pH}$ of 6.58 , electrical conductivity of $207 \mathrm{mS} / \mathrm{cm}$ and $\mathrm{HCO}_{3}$ content of $7625 \mathrm{mg} / \mathrm{l}$ (Kis, 2013). Researches on the chemical and isotopic composition of the gases were made by Vaselli et al. (2002), Italiano et al. (2017) and Ionescu et al. (2017). The chemical composition of the dissolved gases is made up mostly by $\mathrm{CO}_{2}(99.25 \%)$ while the other components are in a much lower concentration: $\mathrm{N}_{2}(0.52 \%), \mathrm{O}_{2}(0.22 \%)$ and $\mathrm{CH}_{4}\left(1.4 \times 10^{-5}\right)$ (Italiano et al., 2017). Similar composition is shown by the free gases that are made up $99.8 \%$ by $\mathrm{CO}_{2}$, $0.28 \%$ by $\mathrm{N}_{2}, 0.005 \%$ by $\mathrm{O}_{2}, 1.9 \times 10^{-3} \mathrm{CH}_{4}$ (Vaselli et al., 2002). 
The origin of the carbon-dioxide is assumed to be related to the alteration of organic matter from the Miocene sediments of the Transylvanian Basin, mixed with a deep component, as shown by the isotopic composition of carbon $\left({ }^{13} \mathrm{C}_{\mathrm{CO} 2}\right)$ of $-9.18 \%$ (VPDB) (Vaselli et al., 2002). The isotopic composition of the dissolved gas $\left({ }^{13} \mathrm{C}_{\mathrm{TDIC}} 2.15 \%\right.$, VPDB $)$ infers intense fractionation processes between the gas and fluid phase (Italiano et al., 2017).

\section{SITE DESCRIPTION}

In the past centuries Dealul Melcului was an aragonite mining site. The Dealul Melcului geological reserve is a shell shaped terrain cut longitudinally by a gorge into two blocks. On the aragonite-travertine walls saline water leakages are observable. The water is gathered in a man-made pool and is drained to feed a saline water bath at the entrance of the reserve.

The gas flux measurements were made in eight points located along the above described gorge (Fig. 2). The measurement points were mostly water surfaces, six of them with stagnant water. The man-made pool was also a measurement point, while the westernmost point where the flux was measured is represented by the main spring of Dealul Melcului.

Our survey was carried out at the end of April, 2017. The meteorological conditions were the following: $713 \mathrm{mmHg}$ atmospheric pressure, relative humidity $43.25 \%$, no precipitation (source: www.rp5.ru).

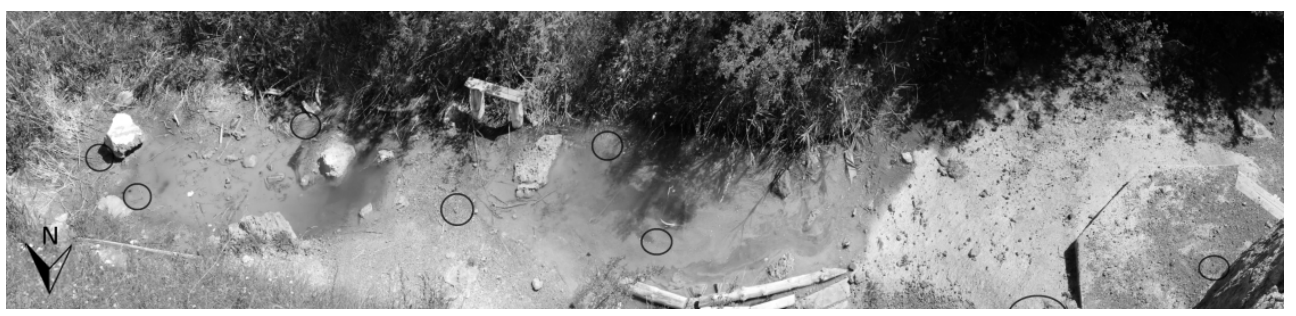

Fig. 2. Panoramic view of the eastern edge of the Dealul Melcului gorge with the location of the gas flux measurement points

\section{METHODOLOGY}

Methane and carbon-dioxide fluxes were measured at the site using the closed chamber method (Fig. 3). The Instrumental package (West System, Pontedera, Italy) is equipped with a $\mathrm{CH}_{4}$ and $\mathrm{CO}_{2}$ sensors and wireless data communication to a smart phone.

The fluxes are automatically calculated using a linear regression of the gas concentration build-up in the chamber. The methane sensor includes semiconductor (range 0-2000 ppmv; lower detection limit of $1 \mathrm{ppmv}$; resolution 1 ppmv), catalytic (range $2000 \mathrm{ppmv}-3 \% \mathrm{v} / \mathrm{v}$ ) and thermal conductivity (range 3\% - $100 \% \mathrm{v} / \mathrm{v}$ ) detectors. The $\mathrm{CO}_{2}$ detector is a double beam infrared sensor (LI- 
COR, with a range of $0-20000$ ppmv, accuracy of $2 \%$ and a repeatability of \pm 5 ppmv) (Baciu et al. 2017). In the case of bubbling pools a funnel was used instead of the accumulation chamber.

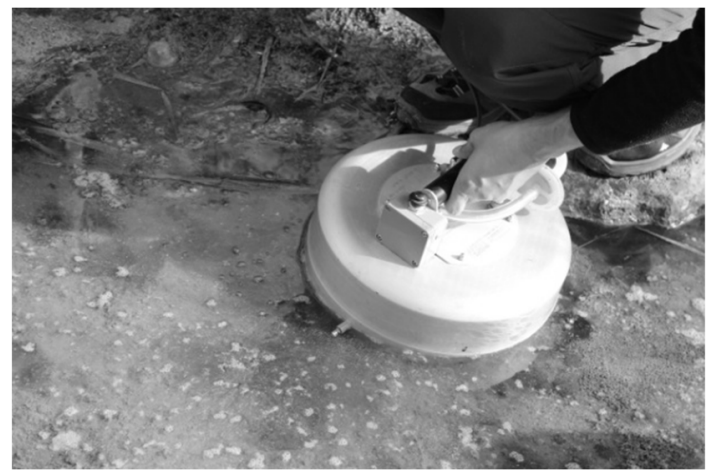

Fig. 3. The closed chamber method used for field measurements

The gas flux for $\mathrm{CH}_{4}$ and $\mathrm{CO}_{2}$ was calculated using the linear regression method, if the rate of increase of the gas concentration in the chamber is constant (F):

$$
F=\frac{V_{c}}{A_{c}} \times \frac{c_{2}-c_{1}}{t_{2}-t_{1}}
$$

where $V_{c}$ is the volume of the chamber, $A_{c}$ is the footprint area of the chamber, $c_{1}$ and $c_{2}$ are the gas concentrations at time $t_{1}$ and $t_{2}$ respectively.

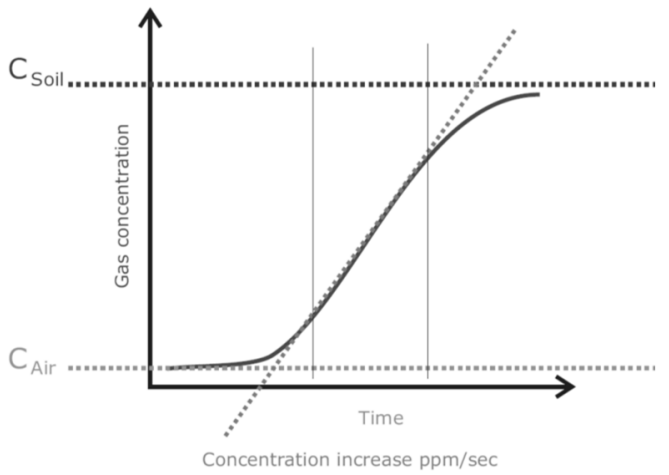

Fig. 4. Method for selecting the optimum slope (concentration increase ppm/sec) for the individual flux measurements

The flux is calculated using the closed chamber technique via the following formula: 


$$
\boldsymbol{F}=\frac{86400 \cdot \boldsymbol{P} \cdot \boldsymbol{V}}{10^{6} \cdot \boldsymbol{R} \cdot \boldsymbol{A} \cdot(\boldsymbol{T}+237)} \cdot \boldsymbol{M} \cdot 1000 \cdot \boldsymbol{a}
$$

where, $F$ is the flux of methane or carbon dioxide $\left[\mathrm{mg} \cdot \mathrm{m}^{-2} \cdot\right.$ day $\mathrm{y}^{-1}$ for $\mathrm{CH}_{4}$ and $g \cdot m^{-2} \cdot$ day $^{-1}$ for $\left.\mathrm{CO}_{2}\right] ; P$ is the barometric pressure [mBar]; $R$ is the universal gas constant, $0.08314510[(\mathrm{bar} \cdot \mathrm{L}) / \mathrm{K}] / \mathrm{mol} ; \mathrm{V}$ is the volume of the accumulation chamber; $A$ is the area of the accumulation chamber; $T$ is the temperature in $K ; a$ is the angular coefficient [ppm/sec] or slope (Fig. 4), and M is the molecular weight of the gas.

The emission is calculated using the Natural Neighbor interpolation method, which takes into account the sharp decrees of flux from a few meters from the vents by performing a weak interpolation. The interpolation method was performed using the Surfer 13 software package developed by Golden Software Ltd.

\section{RESULTS AND DISCUSSION}

Our measurements show the domination of carbon-dioxide among the emanated gases. Its flux shows values between $40.38 \mathrm{~g} / \mathrm{m}^{2} /$ day and 458.85 $\mathrm{g} / \mathrm{m}^{2} /$ day. The methane was detectable, but it didn't exceed the concentration that characterizes the atmospheric air.

On our study area there is one high carbon-dioxide emitting point, while at two other points the emissions can be considered increased as well.

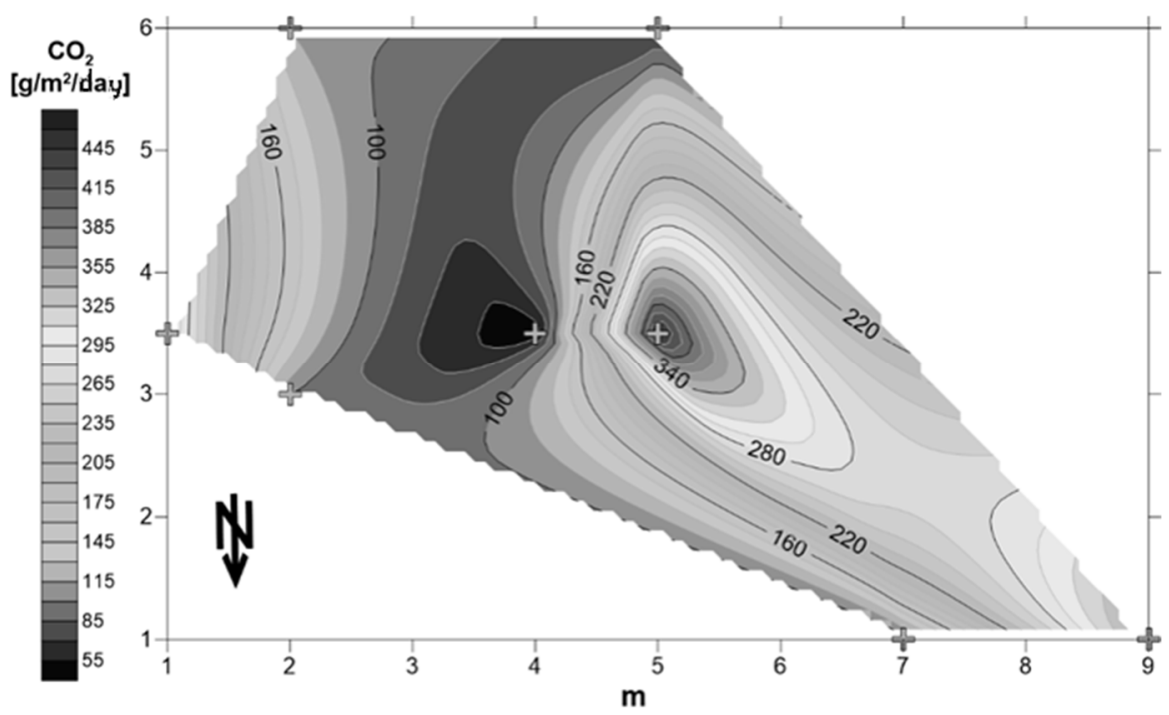

Fig. 5. Representation of the $\mathrm{CO}_{2}$ gas fluxes on our study area-crosses mark the measurement points 
The investigated area can be divided into three zones: (1) a higher emanating zone on the western side, (2) low emanation in the central part, and (3) slow increase of the $\mathrm{CO}_{2}$ flux on the easternmost side (Fig. 5).

The carbon-dioxide flux at the main spring (the westernmost measurement point) is $350.88 \mathrm{~g} / \mathrm{m}^{2} /$ day that is increasing towards the center of the study area where the maximum flux was detected, $458.86 \mathrm{~g} / \mathrm{m}^{2} /$ day. The main spring showed artesian behavior and often migrated from the upwelling point. The travertine deposits are thick and compact enough to block the path of the gas so this migrates to the periphery of the hill. The gas flux becomes higher at those points where the pressure of the blocks is lower or where fissures are present in the travertine rock. This is supported also by the evidence given from the calcite and aragonite crystals which developed also in fissures that were traversed by such migrating fluids.

A pronounced change is observable at the central part of the site that is indicated by the occurrence of the lowest flux with the value of $40.39 \mathrm{~g} / \mathrm{m}^{2} /$ day. The gas emission shows a slow increase again at the easternmost measurement point.

Between the two points characterized by the highest fluxes there were no additional measurements, so it might be that a lower emanation zone separates these two points. The presence of the lowest emanation zone in the central part of the study area is much more realistic since it is supported by four low fluxes between $40.38-114.28 \mathrm{~g} / \mathrm{m}^{2} /$ day.

Adding together all the data that were measured at Dealul Melcului geological reserve, an average value of 1.329 t/year carbon-dioxide emission can be estimated.

\section{CONCLUSIONS}

The goal of our measurements was to quantify the gas emissions from Dealul Melcului area and by adding the results of our measurements to the data and information available from previous works to have a complete view about the presence of geogenic methane and carbon-dioxide at this site. Our work revealed that no geogenic methane is emitted, while there are $1.329 \mathrm{t} / \mathrm{year}$ carbon-dioxide emissions to the atmosphere.

The results of our measurements can be positively attached to those of previous works. It is generally considered that aragonite is deposited from highly saline, $\mathrm{CO}_{2}$ rich mineral waters (Tóth, 2002). Vaselli et al. (2002) demonstrated that the most abundant component of the free gas is $\mathrm{CO}_{2}(99.8 \%)$. The same author, based on isotopic composition, suggested that the Corund North gases have a deep origin possibly due to thermometamorphism of carbonates in the subsurface. The same deep origin was also suggested for the waters in the works of Kis (2013) and Italiano (2017). Our measurements revealed that the maximum free $\mathrm{CO}_{2}$ gas flux is $458.86 \mathrm{~g} / \mathrm{m}^{2} /$ day supporting the $\mathrm{CO}_{2}$ rich environment. The average carbon-dioxide yearly emission at Dealul Melcului geological reserve is estimated to be $1.329 \mathrm{t}$. 
Free and dissolved gas measurements were made at other sites in Corund area as well (Kis, 2013 and Pop, 2014) but these are sporadically distributed. To have a general overview about the free gas emissions and the subsurface system which feeds the emission sites, additional flux measurements are needed for the Corund area combined with isotopic compositions of the gases and of the waters.

\section{REFERENCES}

1. Baciu, C., Ionescu, A., Etiope, G. (2017), Hydrocarbon seeps in Romania: Gas origin and release to the atmosphere. Marine and Petroleum Geology, 89, 1, 130143.

2. Ciupagea, D. T., Păucă, M., Ichim, T. (1970), Geologia Depresiunii Transylvaniei. Editura Academiei Republicii Socialiste România, București

3. Erdődi, J. (1839), Egy nap Korondon. Nemzeti Társalkodó, II/15, 117-119

4. Ianovici, V., Rădulescu, D. (1968), Harta geologică a Republicii Socialiste România, Nr. 20 Odorhei, scara 1:200.000, Institutul Geologic, București

5. Ionescu, A., Baciu, C., Kis, B. M., Sauer, E. P. (2017), Evaluation of dissolved light hydrocarbons in different geological settings in Romania. Chemical Geology, 469, 230-245.

6. Italiano, F., Kis, B. M. (corresponding author), Baciu, C., Ionescu, A., Harangi, Sz., Palcsu, L. (2017), Geochemistry of dissolved gases from the Eastern Carpathians-Transylvanian Basin boundary. Chemical Geology, 469, 117-128.

7. Kis, B. M. (2013), Hydrogeochemistry of mineral waters from the Eastern Carpathians-Transylvanian Basin boundary. PhD Thesis, Babeș-Bolyai University, Faculty of Environmental Science and Engineering, Cluj-Napoca

8. Krézsek, Cs., Bally, A. W. (2006), The Transylvanian Basin (Romania) and its relation to the Carpathian fold and thrust belt: Insights in gravitational salt tectonics. Marine and Petroleum Geology, 23, 405-442.

9. Pop, C. I. (2014), Emisii geogene de metan în Platforma Moldovenească şi Bazinul Transylvaniei. PhD Thesis, Babeș-Bolyai University, Faculty of Environmental Science and Engineering, Cluj-Napoca

10. Seghedi, I., Szakács, A., Snelling, N. J., Pécskay, Z. (2004), Evolution of the neogene Gurghiu Mountains volcanic range (Eastern Carpathians, Romania) based on K-Ar geochronology. Geologica Carpathica, 55, 4, 325-332.

11. Tóth, A. (2002), Contributions on the mineralogy of the Corund carbonate deposit. Studia Geologia, 47, 149-159.

12. Vaselli, O., Minissale, A., Tassi, F., Magro, G., Seghedi, I., Ioane, D., Szakács, A. (2002), A geochemical traverse across the Eastern Carpathians (Romania): constraints on the origin and evolution of the mineral waters and gas discharge. Chemical Geology, 182, 637-654.

13. https://rp5.ru/, accessed on June, 06, 2017 